Journal of Engineering Sciences, Assiut University, Vol.40, No. 5, pp.1337-1349, September 2012.

\title{
IMPROVEMENT OF SWELLING CLAY PROPERTIES USING HAY FIBERS
}

\section{Abd el megeed kabasy Mohamed}

Associate Professor, Civil Eng. Dept., Faculty of Engineering, Assiut University, Egypt Current Address: Civil Eng. Dept., Faculty of Engineering, Taif University, Saudi Arabia

(Received July 10, 2012 Accepted July 21, 2012)

Soil stabilization by lime, fly ash, and different chemical additives were used to improve the swelling characteristics of the clayey soil. In the present study, the hay fibers of wheat is added to a clayey swelling soil to improve and stabilize its characteristics. Old houses in Egyptian villages were built with clay mixed with hay fibers as a cementious agent between clay particles. The hay ratio used in the present study was 0.5, 1 and 1.5\% by weight of the clayey soil. The soil used in this study represents a type of swelling clayey soil. Index, strength and swelling properties tests are carried out on the clay-hay mixture. The results showed that the shear strength increases with the increase of hay ratio till approximately $1 \%$ hay addition. The indirect tensile strength for air dried samples increased as well. The deformation due to the swelling potential also decreased to about $20 \%$.

Keywords: Hay; swelling; Barazilian test; stabilization; fibers.

\section{INTRODUCTION}

Swelling clays are found in many parts of the world, particularly in semi-arid areas. Swelling clays are detected in Australia, Canada, China, Jordan, Saudi Arabia, India, South Africa, Sudan, Egypt, and the United States. The expansive soil term is used for soils that have potential shrinkage and swelling property under changing water content.

Swelling soils in Egypt are found in different areas such as Madinat Nasr, Sina, Assiut, the New Valley, Sohag, etc. Although a considerable progress had been made to overcome this problem but no definite theoretical analysis has been established. This may be due to the complex interaction of the soil-cations minerals with water. In cases where the surface layer only is found as expansive clay, it can be replaced by clean sand or admixture of gravelly sand. Sometimes, a protective procedure should be applied to prevent the access of the free water to the soil i.e., constructing the foundation at depths not subjected to the changes in the water table. However, in embankment construction, if the soil of the embankment was a swelling soil, it must be treated with some additions before construction. Egyptians used hay in houses, by adding it to the clay pastel. They built their houses from pastels of clay mixed with hay in their plastic state and left it until getting dry. This efficient method contributed to the stability of the houses they built. For economic purposes, the construction of highways necessitates using the local soil in the field. This problem may be overcome by converting or improving the swelling properties of soil using appropriate additives. 
Lime is one of the most common and successful soil stabilizers. Some chemical additives are used with lime, and are found to be useful in accelerating the interaction between lime and soil. These chemical additives are not widespread due to their high cost. Stabilizing of swelling soil by lime requires months to react and reach equilibrium state with soil.

The main objective of this research is studying the effect of hay addition to an expansive soil, on its strength and swelling properties. Hay is cheap and is found all over the world. Hay is added to an expansive clayey soil from Sohag province in Egypt as a percentage of soil weight.

Extensive studies have been carried out on the stabilization of expansive soils using various additives such as lime, cement, fly ash, industrial waste products, potassium nitrate, calcium chloride and phosphoric acid, [2], [3], [7], [9], [11] and [13]. Mat, et al [14] considered the potential of gypsum, organic polymers, organic matter waste materials, and fly ash, as soil stabilizers. Addition of gypsum to soil can limit clay swelling and dispersion, and improve soil structural stability. Synthetic organic polymer addition to soil surface aggregates leads to their stabilization, improves bonding between adjacent aggregates, and clay flocculation. Fly ash additives can improve soil physical characteristics such as texture, structure, water holding capacity, hydraulic properties, and aeration [10]. In Al-Khod (northern Oman), a swelling clayey soil was treated with cement by-pass dust (CBPD), the formation of aggregations as a result of the clay cement interaction had reduced the clay potential of swelling [12].

Lime is widely used in civil engineering applications such as road construction, embankments, foundation slabs and piles. It has been indicated , [3], that the addition of lime significantly reduces the swelling potential, liquid limit, plasticity index and maximum dry density of the soil, and increases its optimum water content, shrinkage limit and strength. The optimum addition of lime needed for maximum modification of the soil is normally between $1 \%$ and $3 \%$ lime by weight, and further additions of lime do not bring changes in the plastic limit, but increase the strength [3]. Generally, the amount of lime needed to modify a clay soil varies from 1 to 3 percent, whilst that required for cementation varies from 2 to $8 \%$ [5] and [6].

Cement stabilization is similar to that of lime and produces similar results. Cement stabilization develops from the cementation links between the calcium silicate and aluminates hydration products and the soil particles. Addition of cement to clay soil reduces the liquid limit, plasticity index and swelling potential and increases the shrinkage limit and shear strength [4], [13].

Sarooj is an Omani local term for artificial pozzolan produced by burning (calcining) clay. Calcined clay pozzolans mixed with lime and water have been used as a cementious material in construction. Heat treatment at elevated temperatures at about $500{ }^{\circ} \mathrm{C}$ and above changes the properties of soils and causes a reduction in their liquid limit and plasticity index. However, this technique seems to be an uneconomical solution [13].

Synthetic fibers such as cellophane, steel or glass wool have found very limited application in the soil stabilizing process. Vegetable oils and fats, tannins, Arabic gum, are used as soil stabilization but they have very slow and limited applications [11]. Fibers are widely used when building with earth. Generally, fibers can be most 
easily mixed in with the soil if it is in a plastic or liquid state. The synthetic fibers serve to increase the tensile strength, reduce density, accelerate drying and reduce cracking by dispersing stresses. Fibers vary in shape, size, strength, elasticity and their bond strength with earth, so possible improvements with different types of fiber will vary, as will the amount of a particular fiber required.

\section{PLAN OF STUDY}

\subsection{Materials}

The soil studied is a silty clay soil. The soil has more than $95 \%$ finer than No.200 sieve. The soil is grey to black color and is quite expansive. The soil is obtained through pit excavated till $2.5 \mathrm{~m}$ depth below the ground surface. A free swell test was carried out and gave a reading of $120 \%$. Therefore, the soil is considered quite expansive. The grains of hay take a longitudinal shape of about 15 to $25 \mathrm{~mm}$ and an approximate thickness of $0.5 \mathrm{~mm}$ as shown in Fig. (1).

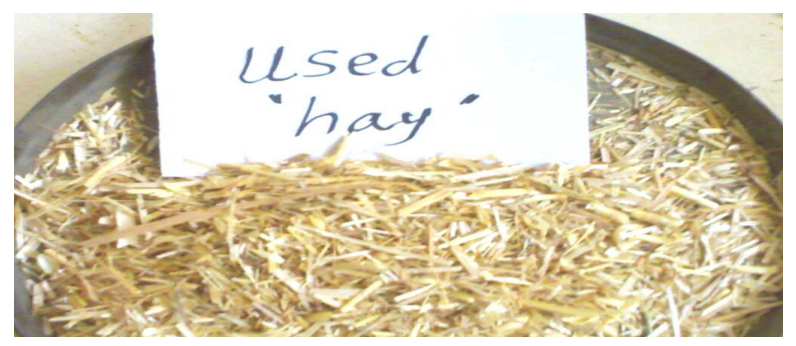

Fig. (1) Photo of used hay

\subsection{Applied Tests}

\subsubsection{Index tests}

The determination of materials finer than No.200 $(75-\mu-\mathrm{m})$ is carried out as described in ASTM D1140-00R06. Liquid Limit, Plastic Limit, and Plasticity Index are carried out as described in ASTM D4318-10. The shrinkage limit is carried out as described in per IS:10077. The standard compaction test is also carried out as described in ASTM D0698-07E01. The free swelling readings are obtained from the application of their standard tests described in per IS: 2727-1977. The results are shown in Table (1).

Table (1): The index properties of the natural clay soil

\begin{tabular}{|c|c|c|c|c|c|c|c|c|c|}
\hline Test & W\% & LL\% & PL\% & I.P\% & S.L\% & $\begin{array}{c}\boldsymbol{\gamma}_{\text {dmax }} \\
\left(\mathbf{t} / \mathbf{m}^{\mathbf{3}}\right)\end{array}$ & o.w.c\% & F.S\% & $\begin{array}{c}\text { \% Finer } \\
\text { No.200 }\end{array}$ \\
\hline Result & 12 & 40.1 & 22 & 18.1 & 10.6 & 1.76 & 17 & 120 & 95 \\
\hline
\end{tabular}

\subsubsection{Strength tests}

To investigate strength properties of the clayey soils, three tests were applied as follows : 
i) The unconfined compression test, as described in ASTM D2166-06.

ii) The direct shear test, as described in ASTM D3080-04.

iii) The indirect tension test on dry samples, as described in ASTM D3967-08.

In each test, the soil is compacted in the standard Proctor mould. The samples are prepared at the maximum dry density with optimum water content.

Standard unconfined compression test as described in ASTM was carried out. The test samples are prepared according to ASTM standard specifications. The sample dimensions are $2.5 \mathrm{~cm}$ in diameter and $6.0 \mathrm{~cm}$ in length, having its maximum dry density with the optimum water content. More than three tests are carried out and the average is obtained. The stress-strain relation is plotted.

The direct shear test is carried out as described in ASTM standard procedures. Samples are prepared at the maximum dry density with optimum water content. A series of tests are carried out on the clayey samples under normal vertical stress applied of $0.5,1.0$ and $1.5 \mathrm{~kg} / \mathrm{cm}^{2}$.

For the determination of materials strength, their tensile strength is of major importance. The direct testing of brittle materials however is very complex. An alternative to this is the indirect testing or the so called Brazilian disk test. A cylindrical specimen is broken in tension perpendicular to one diameter, by applying compressive force $(\mathrm{F})$ in a direction perpendicular to this diameter $(D)$. The load is increased slowly until specimen breaks. The test is a good one for brittle materials that have shear strength greater than their tensile strength. The diameter of specimen is one half its length L. This test has been for concrete testing since long time [1]. The Brazilian test set is shown in Fig. (2).
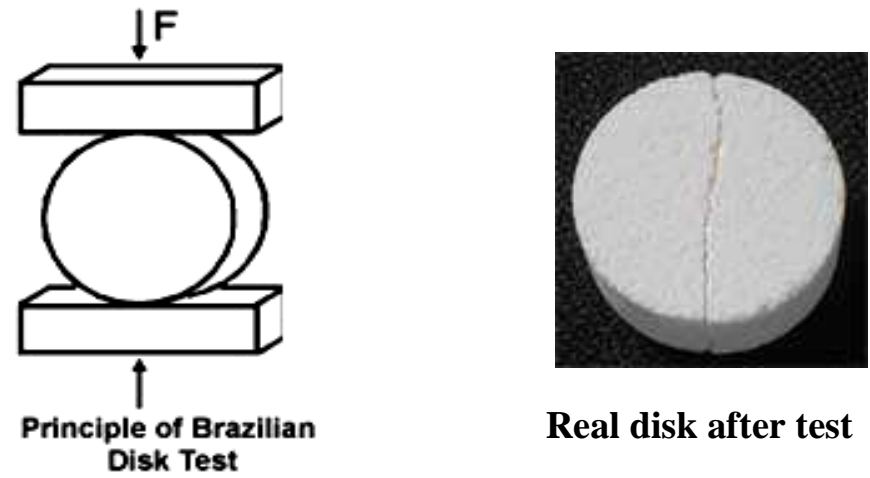

Real disk after test

Fig. (2) Schematic diagram of Brazilian indirect tension test.

For samples with length $L=2 D$, the tensile stress can be determined as in Equ.(1): $\sigma_{t}=\frac{2 F}{\pi D L}$

where, $D$ and $L$ are the diameter and length of the cylindrical samples.

\subsubsection{Swelling tests}

To know the essential swelling properties, the following tests were carried out: 
i) Free swell test as described in per IS:2727-1977.

ii) Swelling pressure test as described in ASTM D4546-08.

Free swell test is carried out following ASTM standard specifications. It is applied to the clay passing sieve No. 40. The results of the free swell test are recorded and the average was determined. The clayey soil without hay addition gives a reading of $120 \%$, which indicates a moderately expansive soil according to the test normative.

The swelling potential tests according to ASTM specification are carried out on clay samples. The clayey soil was put in the mould of the consolidation test at max dry density and optimum water content. The soil is loaded with $0.25 \mathrm{~kg} / \mathrm{cm}^{2}$ vertical stress to simulate the small buildings in field. The distilled water is applied to the specimen until saturation. A dial gauge is installed over the specimen with zero reading. The increase in the reading of the dial gauge is recorded each day. After three days, the reading begins to be constant, which means that the soil reached the maximum swelling potential under $0.25 \mathrm{~kg} / \mathrm{cm}^{2}$. The swelling of the soil sample without any addition, after three days under a pressure of $0.25 \mathrm{~kg} / \mathrm{cm}^{2}$, was $0.83 \mathrm{~mm}$.

\section{EXPERIMENTAL WORK}

\subsection{Adding Hay as a Percentage of Soil Weight}

The liquid, plastic and shrinkage limits are obtained for each clay-hay mixture. The compaction test is carried out on each mixture. The results are summarized in Table (2), Figs. (3), (4) and (5).

Table (2)

\begin{tabular}{|c|c|c|c|c|c|}
\hline $\begin{array}{c}\text { Hay } \\
\text { addition\% }\end{array}$ & $\begin{array}{c}\text { Liquid } \\
\text { limit\% }\end{array}$ & $\begin{array}{c}\text { Plastic } \\
\text { limit\% }\end{array}$ & $\begin{array}{c}\text { Plasticity } \\
\text { index\% }\end{array}$ & $\begin{array}{c}\text { Shrinkage } \\
\text { limit\% }\end{array}$ & $\begin{array}{c}\text { Free } \\
\text { swelling\% }\end{array}$ \\
\hline Without & 40 & 22 & 18 & 10.6 & 120 \\
\hline With 0.5 & 40 & 25 & 15 & 9.6 & 110 \\
\hline With 1.0 & 41 & 22 & 19 & 5.3 & 105 \\
\hline With 1.5 & 38 & 24 & 14 & 12.6 & 100 \\
\hline
\end{tabular}

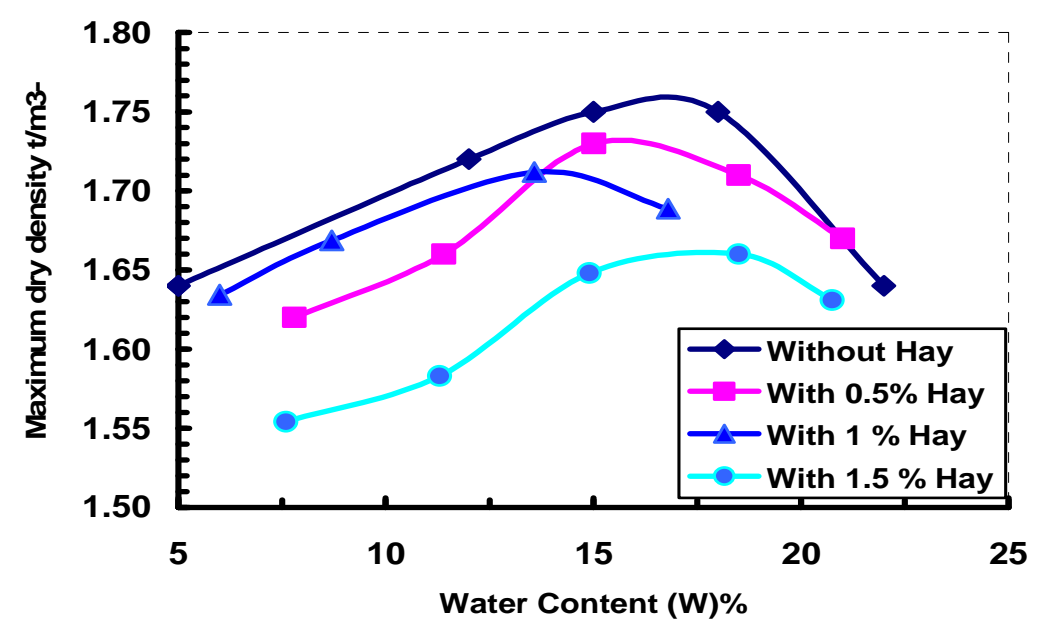

Fig. (3) Maximum dry density with and without hay addition 


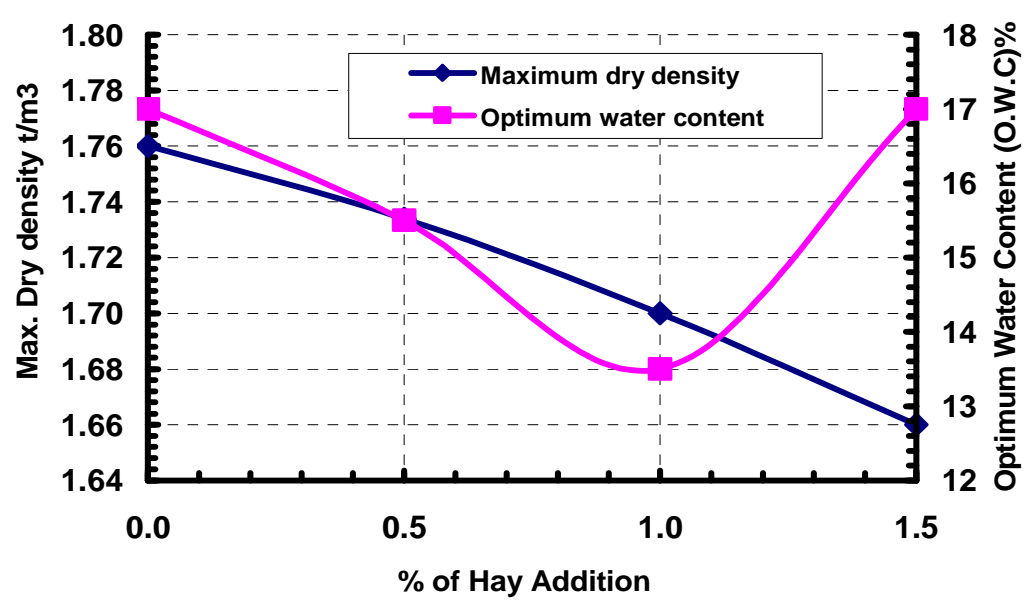

Fig. (4) Optimum water content and maximum dry density

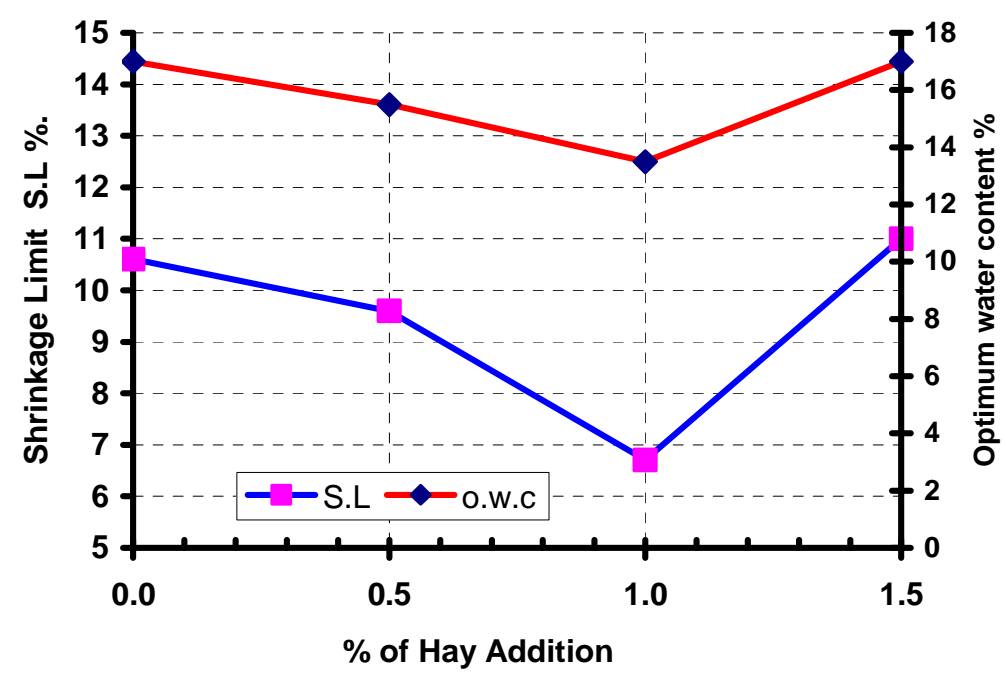

Fig. (5) Comparison between S.L and Optimum water content

\subsection{Strength Properties of the Clay-Hay Mixture}

As mentioned above, $0.5 \%, 1.0 \%$ and $1.5 \%$ of hay is added to the clayey soil as a percentage of the soil weight. The samples are taken from standard compaction mould with its optimum water content and maximum dry density determined before. The unconfined compression test is carried out on many samples and the average is obtained. The samples were cylindrical with diameter of $2.5 \mathrm{~cm}$ and $6.0 \mathrm{~cm}$ in length. The results are shown in Figs. (6) and (7).

Also, the direct shear test is carried out on the clay-hay mixture. The compaction is carried out using the optimum water content and maximum dry density of the mixture as mentioned in the past paragraph. Three tests were carried out. The first was under $0.5 \mathrm{~kg} / \mathrm{cm}^{2}$ as a normal stress. The second and the third were at 1.0 and $1.5 \mathrm{~kg} / \mathrm{cm}^{2}$, respectively. The test is carried out till failure and the results are shown in Fig. (8). 


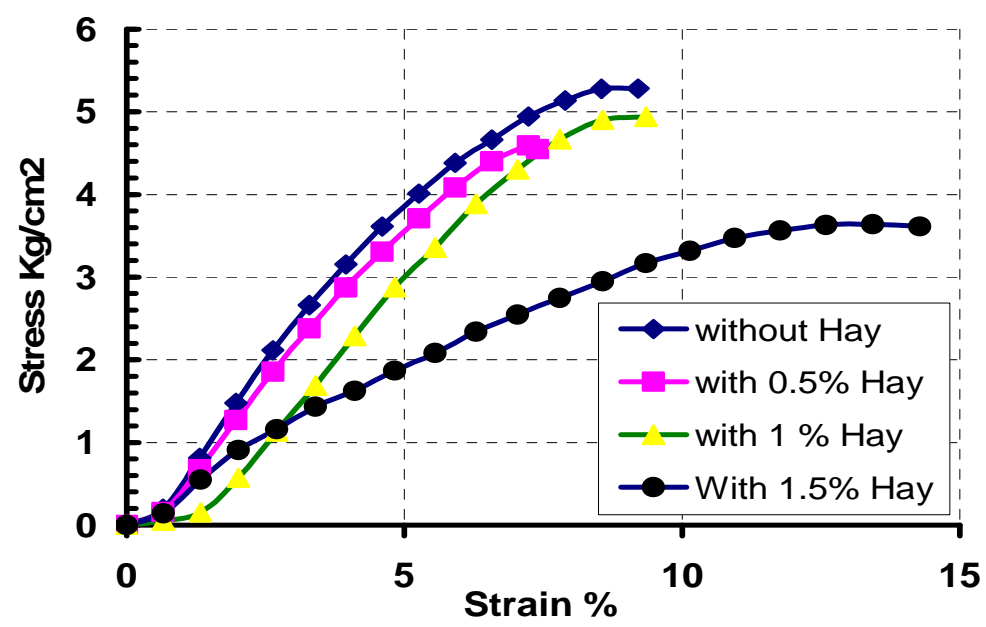

Fig. (6) Results of unconfined compression test

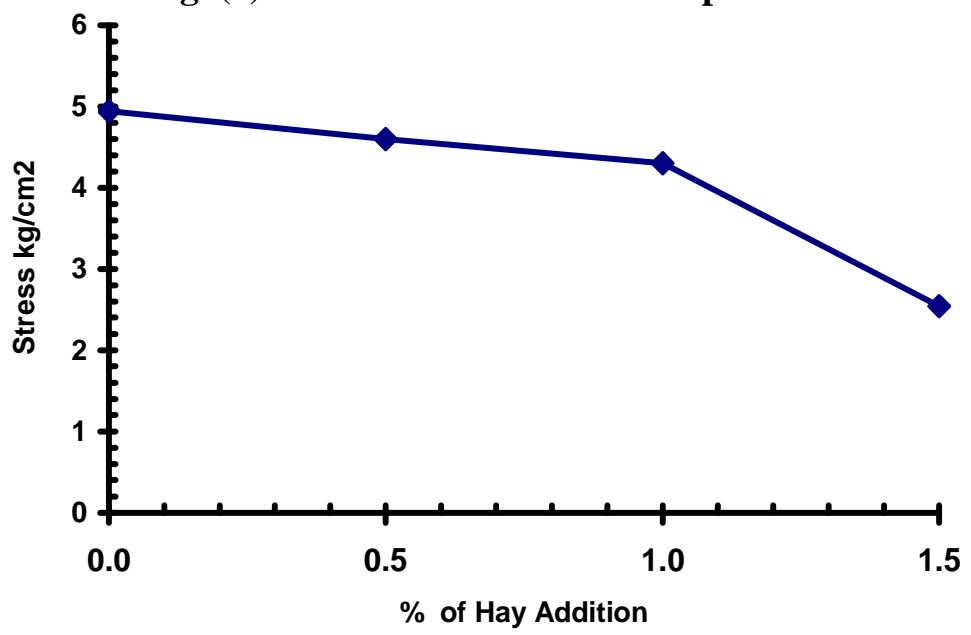

Fig. (7) Hay ratio with the unconfined compressive strength

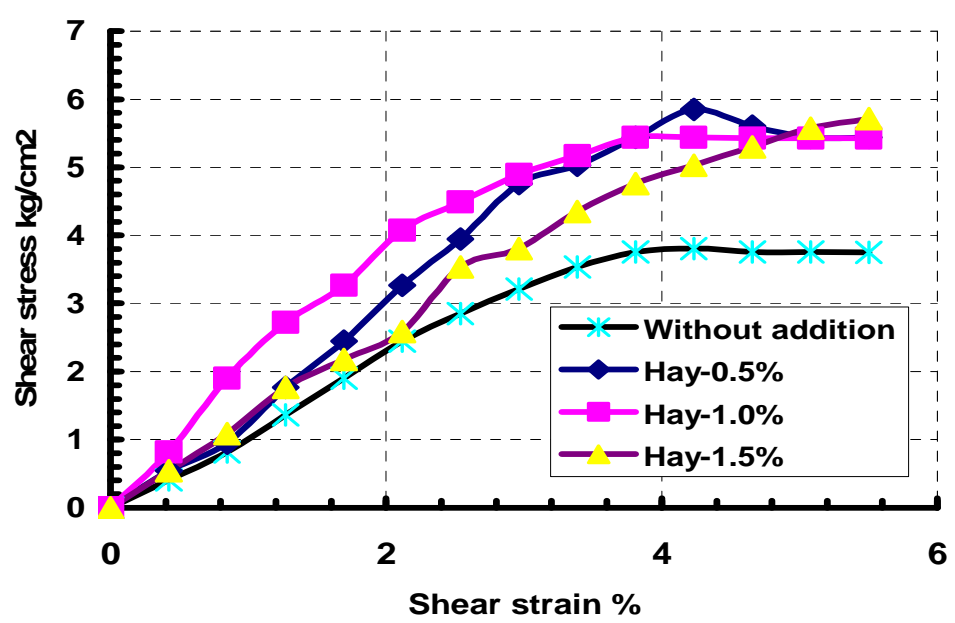

Fig. (8) Direct shear test under vertical stress of $1.0 \mathrm{~kg} / \mathrm{cm}^{2}$ 


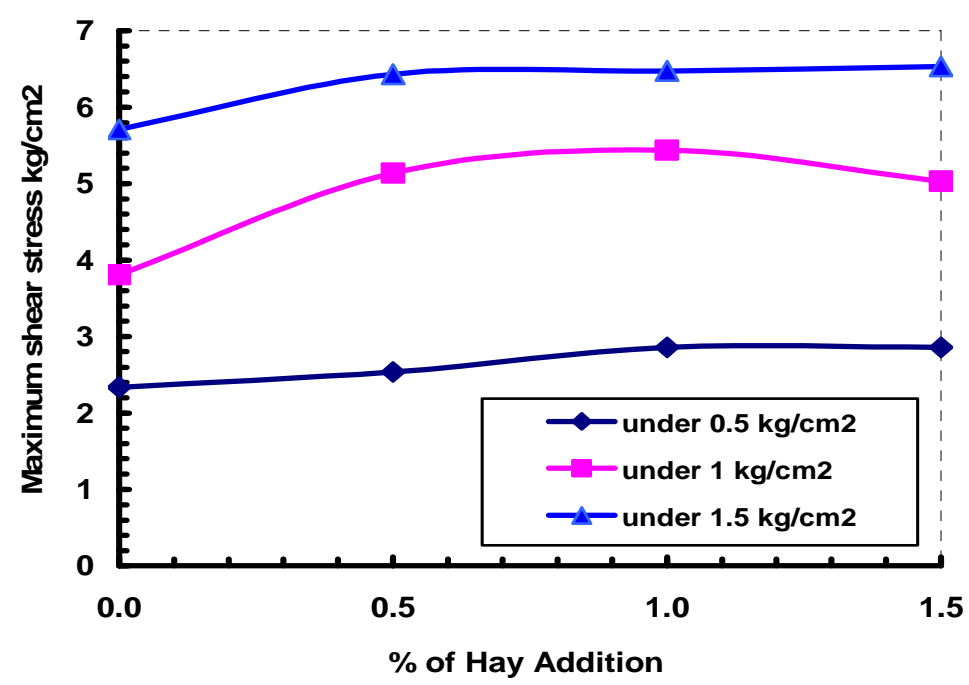

Fig. (9) Shear strength under $0.5,1.0$, and $1.5 \mathrm{~kg} / \mathrm{cm}^{2}$

The indirect tension test is carried out on cylindrical samples with length equal to twice the diameter in the Brazilian test machine. The rate of loading was $10 \mathrm{~kg} / \mathbf{s}$. Fig. (10) represents a photo of the Brazilian test set. The results of the indirect tension tests are shown in Fig. (11).

\subsection{Swelling Properties of the Clay-Hay Mixture}

Free swell test is applied on each clay-hay mixture and the results are summarized in Table (2).

Swelling potential test is carried out through a consolidation cell loaded with 0.5 $\mathrm{kg} / \mathrm{cm}^{2}$ as initial conditions. The test is carried out according to the steps mentioned before. The dial gauge reading is recorded after three days for each mixture. The test is repeated at least three times for certainty and the average is taken. The results are shown in Figs. (12) and (13).

Table (2) contains the index properties of the clay with and without hay addition. The liquid and plastic limits have no considerable changes.

Shrinkage limit, one of the Atterberg limits, is widely linked with many plasticity-based soil behaviors. However, in a great majority of these cases, such correlations have been found to exhibit poor performance. Recently, it has been brought out that the shrinkage limit of a natural soil does not depend upon plasticity characteristics, and it is primarily governed by the relative grain size distribution of the soil [3]. The shrinkage limit has considerable variations, for example in Fig. (5) the shrinkage limits decrease with the increasing of hay addition until $1.5 \%$ which begins to increase. This behavior is very close to the behavior of the optimum water content which means that the shrinkage limit does not depend on the plasticity of the soil rather than the particle size distribution as in Fig. (5).

The compaction results of the clay-hay mixture also have a considerable behavior changes. In Figs. (3) and (4), the optimum water content with maximum dry density is plotted. From these curves, it can be seen that the maximum dry density decreases 
with increasing of hay percentage. This is a normal behavior because the weight of the dry soil decreases with the increasing of hay addition. Also, the optimum water content decreases with the increasing of the hay addition till $1.5 \%$ hay percentage, which tends to increase gradually. The behavior of the optimum water content is approximately the same as the behavior of the shrinkage limit of the clay-hay mixtures.

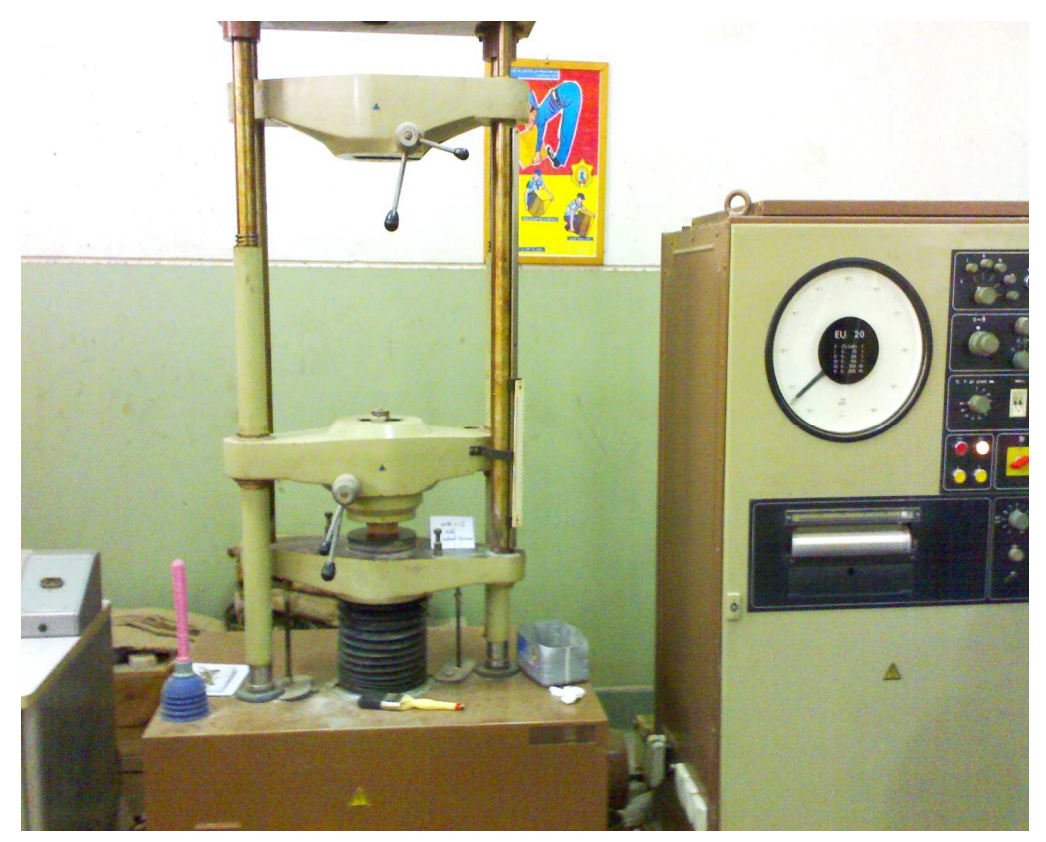

Fig. (10) Photo of the Brazilian indirect tension test machine

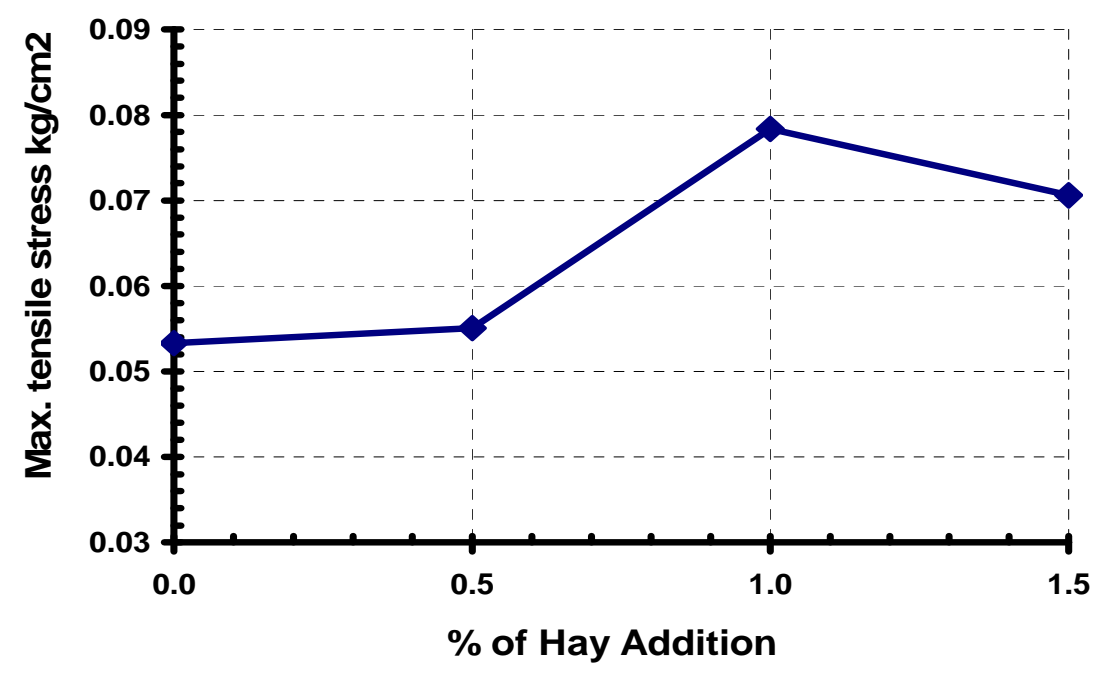

Fig. (11) Indirect tension test for air dried samples (Barazilian test) 


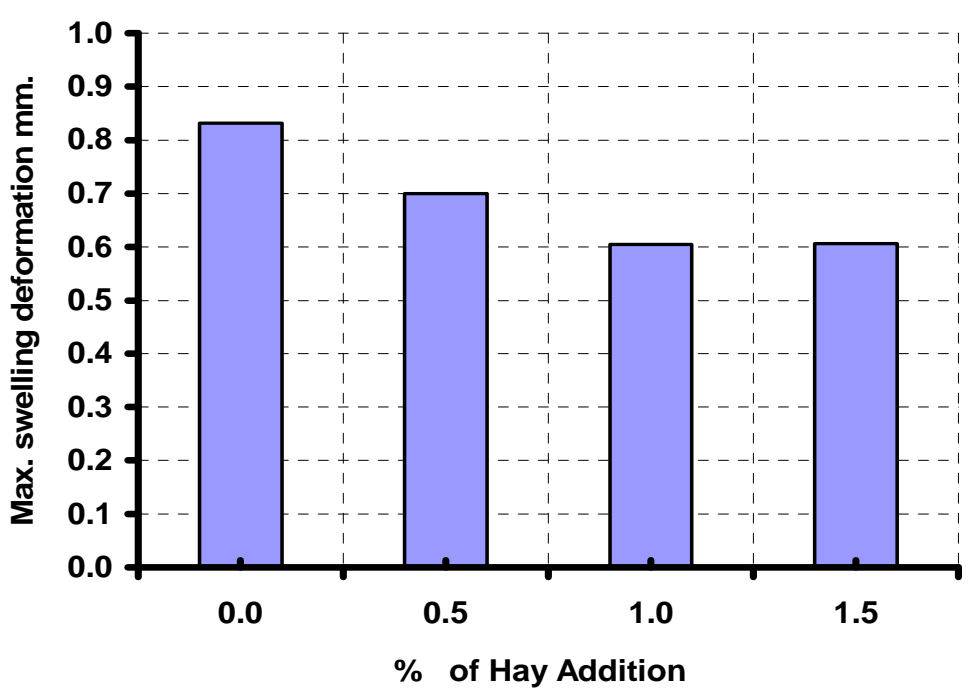

Fig. (12) Maximum swelling deformation with and without Hay addition

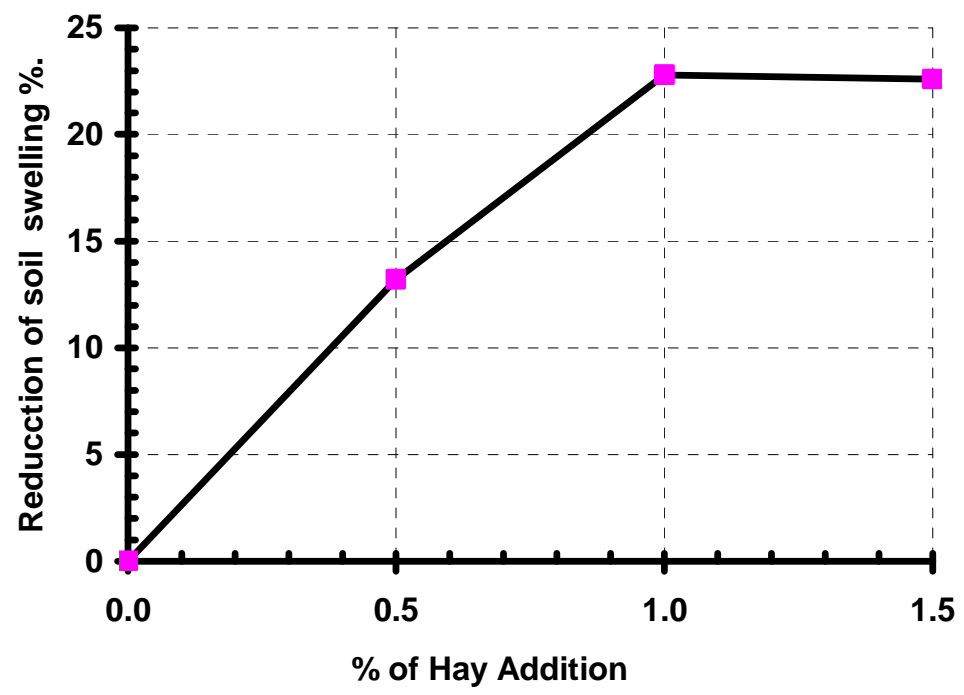

Fig. (13) Reduction of swelling deformation with hay addition

\section{RESULTS AND DISCUSSIONS}

\subsection{Index Properties}

\subsection{Strength Properties}

Figures (6) and (7) show the relation between unconfined compression stresses and the deformations. The increase of hay percentage is associated with decrease of compression strength of the mixture. This may be due to the fact that the addition of fibers to clay weakens the ability of the clay to withstand compression forces. This can 
be due to the fact that the hay grains create weak planes in the clay pastel which accelerates the failure.

Figures (8) and (9) show the relation between the maximum shear stress and the percent of hay addition. In general, the addition of hay to the clayey soil increases the shear stress of the soil. The shear stress increases with the increasing of the normal stress on the samples as shown in the Fig. (8). The best ratio of the hay addition seems to be $1 \%$. The hay grains make cementation links between the clay particles which help increase its shear strength.

The indirect tension, Fig. (10), was applied to the clay-hay mixture samples. This test is carried out on air dried samples to see the effect of hay addition on the tensile strength of the dry clay samples. These tests are carried out to know more about the phenomenon of building houses by Egyptian villagers, with clay-hay mixture. The results showed that the addition of hay to the clayey soil increases its tensile strength. The best ratio of hay seems to be $1 \%$ which gives the maximum tensile stress for the air dried clayey samples mixtures as shown in Fig. (11). The walls of the old village houses carry the vertical loads, which converts to small horizontal forces in the clay mixture blocks which induce tensile stresses. The hay grains make a cementation between clay particles which represent, in this case, a type of reinforcement.

\subsection{Swelling Properties}

Two swelling tests are carried out on each of the clay-hay mixtures. The first is the free swell test and the results of this test are tabulated in Table (2). From the table, it is obvious that the free swelling value decreases (with low values), with the increasing of hay addition as shown in Table (2). This can be due to floating hay above the water in the jar of the free swell test.

The second test on the samples mixture is the swelling potential test. The test is carried out as mentioned before. A vertical stress of $0.25 \mathrm{~kg} / \mathrm{cm}^{2}$ is applied on the samples to simulate the field conditions. In the field, approximately the small buildings only which can run the risk of swelling. For that reason, a vertical stress of $0.25 \mathrm{~kg} / \mathrm{cm}^{2}$ is applied on the samples. Figures (12) and (13) show the maximum swelling deformation for each mixture. From these figs., one can conclude that the addition of $1 \%$ hay decreases the swelling deformation from $0.83 \mathrm{~mm}$ to $0.60 \mathrm{~mm}$. As a result, the swelling deformation was reduced to about $23 \%$ of its original value without adding hay.

\section{CONCLUSIONS}

From the present study of adding hay to clayey soil, the following conclusions can be derived:

1. No considerable or reasonable changes in the Atterberg limits occur due to addition of hay.

2. The maximum dry density decreases with hay addition till $1 \%$. The optimum water content decreases with increasing hay addition till $1 \%$ addition and begin to increase with increasing hay addition.

3. The shrinkage limit decreases with increasing hay addition till $1 \%$ addition and increase with higher hay addition. 
4. The unconfined compression strength of the clay decreases with the increasing of the added hay ratio.

5. The direct shear strength of the clay increases notably with hay addition till $1 \%$. This increase is approximately more than $20 \%$.

6. The tensile strength of the air dried hay-clay mixtures, increases with the increasing ratio of hay. The increase of the tensile strength is about $30 \%$ with $1 \%$ hay addition. The best ratio of hay addition seems to be $1 \%$.

7. The swelling potential under $0.25 \mathrm{~kg} / \mathrm{cm}^{2}$ decreases with hay addition. The decrease is about $20 \%$ with $1 \%$ hay ratio.

\section{REFERENCES}

[1] Barla, G. and Innaurato, N.,'Indirect tensile testing of anisotropic rocks". Rock Mech 5, pp. 215-230, 1973.

[2] Basma AA, Tuncer ER., "Effect of lime on volume change and compressibility of expansive clays". Transportation Research Board, Washington DC, TRR No. 1296, pp. 54-61,1991.

[3] Sherwood. PT., "Soil stabilization with cement and lime: state-of-the-art review". Transport Research Laboratory, London: Her Majesty's Stationery Office,1993.

[4] Rao, S.M., Sridharan, A. and Ramanath, K.P., "Collapse behavior of an artificially cemented clay". ASTM Geotechnical Testing Journal 18, pp. 334$341,1995$.

[5] Greaves H., "An introduction to lime stabilization. Proceedings of the Seminar on Lime Stabilization", Loughborough University, pp. 5-12, 1996.

[6] Rogers, C.D.F., Glendinning, S., "Modification of clay soils using lime. Proceedings of the Seminar on Lime Stabilization", Loughborough University, pp. 99-114., 1996.

[7] Miller, G. and S. Azad., "Influence of soil type on stabilization with cement kiln dust". Construction and Building Materials 14 (2), pp. 89-97,2000.

[8] Sridharan, A.; Prakash K., "Shrinkage limit of soil mixtures". ASTM geotechnical testing journal ISSN 0149-6115 CODEN GTJODJ Source / Source, vol. 23, no.1, pp. 3, 2000.

[9] Nalbantoglu Z. and E. Gucbilmez., "Improvement of calcareous expansive soils in semi-arid environments". Journal of Arid Environments 47 (4), pp. 453-463., 2001.

[10] Rao, S.M., Venkatarama Reddy, B.V. and Muttharam, M., "Engineering behavior of wood-ash modified soils". Ground Improvement (Institution of Civil Engineers, London) Vol. 4, pp. 137-140, 2001.

[11] Amer Ali Al-Rawas, R. Taha, J.D. Nelson, T. Beit Al-Shab and H. Al-Siyabi., "A comparative evaluation of various additives used in the stabilization of expansive soils". Geotechnical Testing Journal, GTJODJ, ASTM 25 (2), pp. 199-209, 2002.

[12] Amer Ali Al-Rawas, "Micro fabric and mineralogical studies on the stabilization of an expansive soil using cement by-pass dust and some types of slags". Can. Geotech. J. 39(5): 1150-1167 Canada, 2002.

[13] Amer Ali Al-Rawas, A.W. Hago and Al-Sarmi., "Effect of lime-cement and Sarooj (artificial pozzolan) on the swelling potential of an expansive soil from 
Oman”. Building And Environment, Volume 40, Issue 5, May, page 681-687, 2005.

[14] Mat. J Et al., "Soil Stabilization in Semiarid and Arid Land Agriculture". Civil Eng., Journal of Materials in Civil Engineering, Volume 18, Issue 2, pp. 190-205 (March/April 2006), ASCE, 2006.

\section{تحسين خواص التربة المنتفشة باستخدام تبن القمح}

تستخدم إضافات كثيرة لتحسين خواص التربة المنتفشة علي مستوي العالم منها الجبر - الرماد أبيلا باستخدام إضافات كيماوية. في هذه الدراسة تم إضافة التبن لتثبيت وتحسين خواص التربة المنتفشة. تبن القدح رخيص و متوفر وكان بيتخدم في صناعة الطوب اللبن في البيوت المصرية القدبية. نسبة التبن المضافة البي عبنات التربة في هذه الدراسة هي 0.5- 1.0- 1.5\% من ونن العبينة. التربة المستخدمة أحضرت من محافظة سوهاج قبلي. أجريت تجارب توصيف التربة والمقاومة والانتفاش علي خليط التربة والتبن و دونت النتائج. النتائج أظهرت أن مقاومة التربة للقص تزد/د بزيادة نسبة التبن في الخليط حتى نسبة 1\% ,.كيضا مقاومة الثد الغير مباشر للعبيات الجافة زادت بزيادة نسبة التبن إلي الطبن. التشكل الناتج عن أقصي جه انتفاش للتربة نقص بقدار 20\% عند إضافة التبن. 